\title{
The utilization of protein and energy during lactation in the rat, with particular regard to the use of fat accumulated in pregnancy
}

\author{
By D. J. NAISMITH, D. P. RICHARDSON AND ANN E. PRITCHARD \\ Department of Food Science and Nutrition, Queen Elizabeth College, University of \\ London, London W8 7 AH
}

(Received 19 January 1982 - Accepted 21 May 1982)

\begin{abstract}
1. The deposition of fat during pregnancy and its subsequent mobilization during lactation was studied in the rat. The utilization of protein during lactation was also investigated.

2. Fat accumulation was rapid and continuous from early pregnancy. Approximately one-third was deposited subcutaneously, the remainder being stored in central depots.

3. The volume of milk produced during lactation was varied by offering protein at two concentrations from day 2 post partum. Optimum lactation was achieved with a high-protein diet. The dams lost no body protein, but $60 \%$ of the total body fat was mobilized, despite a marked increase in food consumption. On a low-protein diet, food intake did not rise during lactation. Some body protein was catabolized and, again, $60 \%$ of the fat was mobilized although milk output, as judged by the gain in carcass energy of their pups, was reduced to approximately one-third of optimum.

4. Protein was used more efficiently by lactating rats, when compared with virgin controls.

5 . We conclude that fat stored during pregnancy makes a major contribution to the energy costs of lactation, and that its mobilization is under hormonal rather than dietary control.
\end{abstract}

During pregnancy adjustments are made to the mother's homeostatic mechanisms that regulate food intake and the metabolism of the nutrients (Naismith, 1980). In the rat, food consumption rises throughout the gestational period. The protein content of the muscles is increased during the first half of pregnancy, and this protein store is later catabolized to supplement the dietary supply of amino acids for foetal growth (Naismith, 1971; Niiyama et al. 1973; Naismith \& Morgan, 1976). Furthermore, the efficiency of protein utilization is greatly increased by suppression of the activity of hepatic enzymes that control amino acid oxidation and the synthesis of urea (Naismith \& Fears, 1971). These alterations in the metabolism of protein in the maternal body are induced by hormones secreted by the foeto-placental unit, and are directed to protecting the foetus from the vagaries of the maternal food supply (Naismith, 1980).

Energy balance also becomes positive in early pregnancy in response to the continuous secretion of progesterone (Hervey \& Hervey, 1967) and the fat store is increased. Opinions differ, however, on the extent, duration and purpose of fat deposition. Beaton et al. (1954) noted a modest $(17 \%)$ increase in carcass fat about mid-pregnancy which disappeared well before parturation, and concluded that fat was catabolized to spare protein for foetal growth. Other workers have found more substantial $(40-50 \%)$ gains in carcass fat in rats killed at term (Spray, 1950; Naismith, 1966). Since considerably less carcass fat was found in dams that had suckled their litters for $14 \mathrm{~d}$ than in virgin controls (Spray, 1950), a more important function might be to subsidize the higher energy costs of lactation.

The aim of the present investigation was to determine the amount and disposition of fat accumulated in pregnancy, and to study its subsequent fate in rats with an optimal or limited lactational performance. Evidence was also sought for the persistance of a more economical use of protein during lactation.

The results of a preliminary study have been reported in abstract form (Naismith, 1971). 


\section{EXPERIMENT A L}

Animals and diets

In all experiments comprising this study, the strain of rat, and the conditions of animal husbandry were identical.

Expt 1. The pattern of fat deposition during pregnancy. Litters of weanling rats of the Sprague-Dawley strain, with a preponderance of females, were maintained on a laboratory stock diet until individual body-weights had reached approximately $200 \mathrm{~g}$. Four female rats which were then closest in weight were selected from each litter and were then assigned at random to four experimental groups. Three animals were mated, pregnancy being dated from the appearance of a mating plug in the food-spill trays below the cages, and the fourth animal served as a non-pregnant control.

On the first day of gestation, the pregnant rats were weighed, and were transferred from stock diet to a high-protein semi-synthetic diet of the following composition $(\mathrm{g} / \mathrm{kg})$ : casein, 250 ; maize starch, 400 ; sucrose, 250 ; and groundnut oil, 100 . To each $\mathrm{kg}$ of this basic diet was added $2.5 \mathrm{~g}$ DL-methionine, $50 \mathrm{~g}$ cellulose powder (Solka floc), $40 \mathrm{~g}$ of mineral mixture, and $20 \mathrm{~g}$ of a vitamin mixture. The composition of the vitamin and mineral mixtures was as described by Naismith et al. (1969).

The rats were housed under thermostatic conditions $\left(22^{\circ}\right)$ in individual screen bottom wire mesh cages, and had free access to food and water. Food consumption was measured at the end of each week. On the 7th (group 2), 14th (group 3) and 21 st (group 4) days of gestation, the animals were weighed, then killed under ether anaesthesia. The gastrointestinal tract, uterus, liver, kidneys and spleen were carefully dissected, adherent fat being returned to the carcass, and the carcasses were analysed for fat. Control animals (group 1) were killed on the day when the first of their littermates became pregnant.

Expt 2. The distribution of fat deposited during pregnancy. Littermate pairs of rats were randomly assigned to two treatments when they had attained a body-weight of $200 \mathrm{~g}$. One of each pair was mated, then both were maintained on the high-protein semi-synthetic diet. Food consumption was measured, and the animals were killed after $21 \mathrm{~d}$.

The uterus and viscera were removed from each rat, any adhering fat being returned to the carcass. The retroperitoneal (lumbar) fat depots were removed in toto from a region between, cranially, the diaphragm, medially, the mid-line, caudally, the inguinal region and, laterally, as far as fat was visible. The ovarian fat depots were also dissected. Subcutaneous fat was measured by skinning the animal, then drying the skin and attached fat before extraction. The eviscerated carcasses were treated in a like manner.

Expt 3. The effect of lactation on body composition. Ten litters of rats were reared on stock diet until body-weights exceeded $200 \mathrm{~g}$. Three females from each litter, selected on the basis of body-weight and rate of growth, were caged individually, mated, and then given the high-protein diet used in the first experiment until their litters had been delivered. The mean body-weight at mating was $234 \mathrm{~g}$. The animals were weighed regularly throughout pregnancy, and food intakes were measured as a means of monitoring their health and the progress of their gestation. On the second day post partum, littermate dams were randomly distributed in three groups. A control group was killed on that day, and dams and the eight heaviest pups from their litters were analysed for fat, water and protein. The litters of the remaining rats were reduced to eight pups in order to standardize the feeding load, and the mothers were allowed to suckle their pups for $14 \mathrm{~d}$. The second group continued to receive the high-protein diet during lactation, but for the third group, maize starch was substituted for part of the casein in the basic diet, reducing the concentration from $250 \mathrm{~g}$ to $110 \mathrm{~g} / \mathrm{kg}$, and the supplement of methionine was discontinued. This diet is referred to hereafter as the low-protein diet. Weights of the dams were recorded on the $2 \mathrm{nd}, 7 \mathrm{th}, 12 \mathrm{th}$ 
and 16th days post partum, and food intakes were measured. At no time was the mother's food accessible to the pups. On day 16, the mothers and their young were killed under diethyl ether anaesthesia for carcass analyses.

Expt 4. The efficiency of protein utilization during lactation. In the final experiment, the capacity of the liver to synthesize urea was compared in lactating rats and in non-pregnant animals. Eight littermate pairs of weanling rats were reared on stock diet to $200 \mathrm{~g}$ body-weight. One rat from each pair was mated and was given the high-protein diet until her pups were born. The diet was then changed on day 2 to the low-protein formula, and she was allowed to suckle eight pups for $14 \mathrm{~d}$. The second rat, which was not mated, was subjected to precisely the same dietary treatment from the day of conception in her littermate.

Food consumption was measured throughout the experiment. On the 16th day post partum the rats were killed, in pairs, by stunning, and the activity of hepatic argininosuccinate synthetase (EC 6.3.4.5) was estimated by the method of Brown \& Cohen (1959). The enzyme activity (i.u.) is defined as $\mu \mathrm{mol}$ urea produced in $60 \mathrm{~min}$.

\section{Analyses for fat and protein}

Carcasses of the dams were eviscerated; those of the pups were not. Each carcass was dried to constant weight in an oven at $105^{\circ}$. The loss of weight gave the water content. The dried carcass was then finely ground in a mortar, transferred to a Soxhlet thimble, and returned to the oven for a further $15 \mathrm{~h}$ to remove any water taken up during the grinding. After drying, the carcass was extracted with light petroleum (b.p. $60-80^{\circ}$ ) in a Soxhlet apparatus until all fat had been removed. Solvent was drained from the thimble at room temperature, and the last traces were evaporated in an oven at $105^{\circ}$. Carcass fat was calculated from the difference in weight of the thimble before and after extraction. Subcutaneous fat was determined in the same way. The total fat content of the retroperitoneal (lumbar) and ovarian fat pads was, however, measured by extraction with a mixture of chloroform and methanol as described by Folch et al. (1957).

For the estimation of protein, the de-fatted carcasses were dissolved in warm concentrated hydrochloric acid, then passed through a sintered glass funnel in order to check the completeness of solution. Samples of the solution, made up to standard volume, were taken for nitrogen determination by the Kjeldahl procedure.

\section{Estimation of the activity of hepatic argininosuccinate synthetase}

The rats were killed by a blow on the head, the livers were rapidly excised, gently blotted and portions were homogenized $(1: 20, \mathrm{w} / \mathrm{v})$ in warm aqueous cetyl trimethyl ammonium bromide $(1 \mathrm{~g} / \mathrm{l})$ for the assay of argininosuccinate synthetase by a modification of the method of Brown \& Cohen (1959). The assay conditions used were the same except that the volumes were increased three-fold, and arginase was omitted from the reaction medium when it was found, in a preliminary study, not to influence the rate of the reaction. Urea formed in the reaction was determined by the method of Ratner (1955).

\section{Statistical analysis}

The results were evaluated statistically using Student's $t$ test for related samples and, where appropriate, two-way analysis of variance and Duncan's multiple range test.

\section{RESULTS}

Expt 1. The pattern of fat deposition was determined in four groups of eight rats killed on days $0,7,14$ and 21 of pregnancy. Mean initial body-weights of the control group and of the pregnant rats on the first day of pregnancy were $214,219,213$ and $216 \mathrm{~g}$ respectively. 


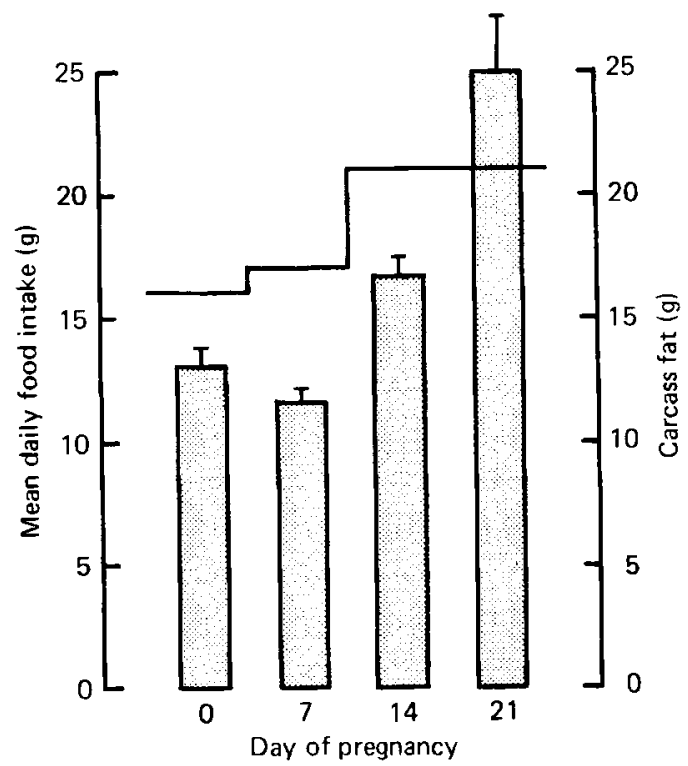

Fig. 1. Total carcass fat in rats at different stages of pregnancy. Values (-) for food intake correspond to consumption before pregancy (0), and during weeks 1 (7), $2(14)$ and $3(21)$ of gestation.

Table 1. Changes in body fat resulting from pregnancy

(Mean values and their standard errors for seven matched pairs of rats per treatment)

\begin{tabular}{|c|c|c|c|c|c|c|c|c|c|c|}
\hline \multirow{2}{*}{$\begin{array}{l}\text { Physiological } \\
\text { status }\end{array}$} & \multicolumn{2}{|c|}{$\begin{array}{c}\text { Total } \\
(\mathrm{g})\end{array}$} & \multicolumn{2}{|c|}{$\begin{array}{l}\text { Ovarian } \\
\text { (g) }\end{array}$} & \multicolumn{2}{|c|}{$\begin{array}{l}\text { Lumbar } \\
\text { (g) }\end{array}$} & \multicolumn{2}{|c|}{$\begin{array}{c}\text { Subcutaneous } \\
\text { (g) }\end{array}$} & \multicolumn{2}{|c|}{$\begin{array}{c}\text { Carcass } \\
\text { (g) }\end{array}$} \\
\hline & Mean & $\mathrm{SE}$ & Mean & SE & Mean & SE & Mean & $\mathbf{S E}$ & Mean & $\mathrm{SE}$ \\
\hline $\begin{array}{l}\text { Non-pregnant } \\
\text { Pregnant }\end{array}$ & $\begin{array}{l}16 \cdot 79 \\
24 \cdot 43^{\text {** }}\end{array}$ & $\begin{array}{l}3 \cdot 2 \\
3 \cdot 0\end{array}$ & $\begin{array}{l}1 \cdot 88 \\
3 \cdot 39 * * *\end{array}$ & $\begin{array}{l}0.40 \\
0.45\end{array}$ & $\begin{array}{l}1 \cdot 19 \\
1.93^{* * *}\end{array}$ & $\begin{array}{l}0 \cdot 17 \\
0 \cdot 26\end{array}$ & $\begin{array}{l}5 \cdot 83 \\
8 \cdot 60^{* *}\end{array}$ & $\begin{array}{l}1.39 \\
1.65\end{array}$ & $\begin{array}{c}7 \cdot 89 \\
10 \cdot 51^{* *}\end{array}$ & $\begin{array}{l}0.86 \\
0.86\end{array}$ \\
\hline
\end{tabular}

Values differ from those for non-pregnant animals: ${ }^{* *} P<0.01,{ }^{* * *} P<0.001$

The animals that were to be used as controls (day 0 ) were given the experimental diet for at least $6 \mathrm{~d}$ before being killed. Food intakes were measured in the pregnant rats throughout the duration of pregnancy, but for comparison the values for the $6 \mathrm{~d}$ immediately before killing were used.

The mean daily food consumption during the first week of pregnancy was not significantly greater than that of the unmated controls (Fig. 1). It then rose sharply $(P<0 \cdot 01)$, and similar values were recorded for the second and final weeks.

Results of the analyses for fat are also shown in Fig. 1. Carcass fat at day 7 of pregnancy appeared to be less than at day 0 , but the difference was not significant. Thereafter, carcass fat increased rapidly with no evidence of fat mobilization as term approached. In this experiment the total gain in fat resulting from pregnancy amounted to $92 \%(P<0.01)$.

Expt 2. The disposition of the additional fat retained during pregnancy was examined by measuring changes in the fat content of four distinct fat depots. Although the mean initial body-weights of the control and pregnant rats (216 and $217 \mathrm{~g}$ respectively) were similar to those in the first experiment, the total increase in body fat resulting from pregnancy $(46 \%$; Table 1) was considerably less, probably a reflexion of the smaller spontaneous rise in food intake $(17 \%$ compared with $23 \%)$. 
Table 2. Effect of the protein content of the diet given during lactation on the weight gains of suckling pups

(Mean values and their standard errors for ten litters per group obtained from matched dams)

\begin{tabular}{|c|c|c|c|c|c|c|}
\hline \multirow{3}{*}{$\begin{array}{l}\text { Maternal diet } \\
\text { during lactation }\end{array}$} & \multicolumn{4}{|c|}{ Weight of pups (g) } & \multirow{2}{*}{\multicolumn{2}{|c|}{$\begin{array}{c}\text { Gain } \\
\text { in weight }(\mathrm{g})\end{array}$}} \\
\hline & \multicolumn{2}{|c|}{ 2-d post partum } & \multicolumn{2}{|c|}{ 16-d post partum } & & \\
\hline & Mean & SE & Mean & SE & Mean & SE \\
\hline Low-protein & $6 \cdot 6$ & $0 \cdot 20$ & $19 \cdot 2$ & $0 \cdot 44$ & $12 \cdot 6$ & $0 \cdot 54$ \\
\hline High-protein & $6 \cdot 2$ & $0 \cdot 12$ & $33 \cdot 2$ & 0.69 & $27 \cdot 0$ & 0.71 \\
\hline
\end{tabular}

Table 3. Effect of the protein content of the diet given during lactation on the body composition of suckling pups

(Mean values for ten litters per group obtained from matched dams)

\begin{tabular}{|c|c|c|c|c|c|c|c|}
\hline \multirow{2}{*}{$\begin{array}{l}\text { Maternal diet } \\
\text { during lactation }\end{array}$} & \multirow{2}{*}{$\begin{array}{c}\text { Time of } \\
\text { killing } \\
\text { (days post partum) }\end{array}$} & \multicolumn{2}{|c|}{ Protein $(\mathrm{g} / \mathrm{kg})$} & \multicolumn{2}{|c|}{ Fat $(\mathrm{g} / \mathrm{kg})$} & \multicolumn{2}{|c|}{ Protein: Water } \\
\hline & & Mean & $\mathrm{SE}$ & Mean & SE & Mean & SE \\
\hline & 2 & 107 & $4 \cdot 1$ & 27 & $4 \cdot 3$ & 0.13 & 0.08 \\
\hline Low-protein & 16 & 127 & $5 \cdot 0$ & 76 & $5 \cdot 2$ & 0.17 & 0.07 \\
\hline High-protein & 16 & $139^{*}$ & $5 \cdot 8$ & $110^{* *}$ & $8 \cdot 0$ & $0 \cdot 19^{* *}$ & 0.04 \\
\hline
\end{tabular}

Values differ from those for low-protein group: ${ }^{*} P<0.05,{ }^{* *} P<0.01$.

All depots showed an increase in fat content. The greatest proportional change was found in the ovarian depot $(80 \%)$, followed by the lumbar depot $(62 \%)$, the subcutaneous fat $(47 \%)$ and the residual fat in the carcass $(33 \%)$. In absolute terms, however, enlargement of the subcutaneous fat depot accounted for the greatest part of the total fat stored $(36 \%)$, although central depots in the carcass other than the ovarian and lumbar regions accounted for almost as much $(34 \%)$.

Expt 3. The effect of lactation on the fat stored in pregnancy was examined in two groups of rats in which the amount of milk produced was varied by adjusting the protein intake after delivery of the pups.

Mean body-weights of the pups were similar on day 2 post partum (Table 2). After $14 \mathrm{~d}$ of lactation, however, the mean gain in weight of the pups suckled by the dams fed the low-protein diet was less than half the gain shown by the pups of mothers maintained on the high-protein diet. This difference was highly significant. $(P<0.01)$, and clearly showed that milk production in the former group had been drastically reduced.

The pups were analysed in order to determine whether those reared by the poorly-nourished dams were simply smaller, or had differences in gross body composition. As expected, the carcasses of the pups of dams given the high-protein diet, being much heavier, contained more protein, fat and water. When the results were expressed on a $\mathrm{g} / \mathrm{kg}$ basis, however, the values became more meaningful (Table 3). During the 14-d suckling period, the proportion of protein and, particularly, fat rose considerably, but marked differences were noted between the low-protein and high-protein groups. The latter group contained more protein $(P<0.05)$ and much more fat $(P<0.01)$. The protein: water for the carcasses of the poorly-nourished pups fell between values for pups killed on day 2 post partum and for the well-nourished pups, suggesting that the process of maturation had been retarded. 
Table 4. Food intakes of dams given a low-protein or a high-protein diet during lactation (Mean values and their standard errors for ten matched rats per group)

\begin{tabular}{|c|c|c|c|c|c|c|c|c|}
\hline \multirow{3}{*}{$\begin{array}{l}\text { Maternal diet } \\
\text { during lactation }\end{array}$} & \multicolumn{6}{|c|}{ Mean daily food intake (g) } & & \\
\hline & \multicolumn{2}{|c|}{$\begin{array}{c}\text { Days } \\
2-6\end{array}$} & \multicolumn{2}{|c|}{$\begin{array}{l}\text { Days } \\
7-11\end{array}$} & \multicolumn{2}{|c|}{$\begin{array}{l}\text { Days } \\
12-15\end{array}$} & \multicolumn{2}{|c|}{$\begin{array}{l}\text { Total food } \\
\text { intake }(\mathrm{g})\end{array}$} \\
\hline & Mean & SE & Mean & SE & Mean & $\mathrm{SE}$ & Mean & SE \\
\hline Low-protein & $26 \cdot 4$ & $1 \cdot 0$ & $23 \cdot 2$ & $1 \cdot 3$ & $24 \cdot 5$ & $2 \cdot 4$ & 346 & 19 \\
\hline High-protein & $25 \cdot 7$ & 0.9 & $35 \cdot 4$ & $1 \cdot 2$ & $45 \cdot 0$ & $2 \cdot 9$ & 485 & 19 \\
\hline
\end{tabular}

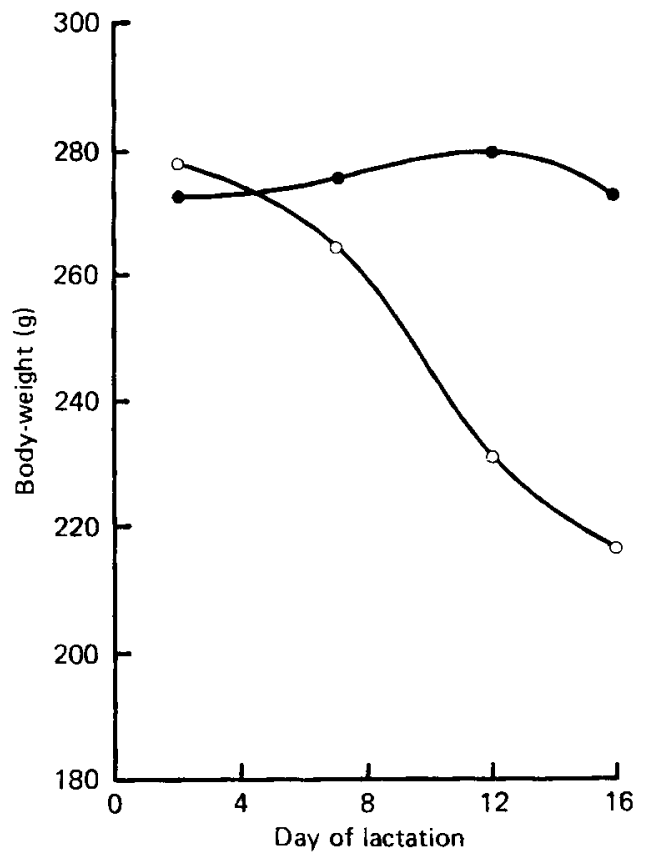

Fig. 2. Changes in body-weight of rats maintained on a high-protein diet during lactation.

The difference in lactational performance between the two experimental groups is partly explained by the difference in the recorded food consumption (Table 4). Rats given the low-protein diet showed no appreciable change in food intake from early lactation. In contrast, food intake rose continuously in the rats given the high-protein diet to reach a level almost double the initial consumption.

Changes in body-weight of the rats during lactation are shown in Fig. 2. Dams given the high-protein diet displayed a modest gain until day 12 , followed by a small loss of weight, whereas their poorly-nourished sisters lost weight continuously from the day on which the protein content of their diet was reduced. The nature of these changes in body-weight was revealed when the rats were killed and analysed at the end of the experiment (Table 5). Both groups of rats had lost approximately $60 \%$ of their total body fat when compared with littermates killed on day 2 post partum. The low-protein group also lost a substantial amount of protein and its associated water, whereas the high-protein group showed a slight but significant increase in body protein, indicating that the dietary protein concentration had been more than adequate to sustain an optimal lactation. 
Table 5. Effect of the protein content of the diet fed during lactation on the carcass composition of the dams

(Mean values and their standard errors for ten matched rats per treatment)

\begin{tabular}{|c|c|c|c|c|c|c|c|c|c|}
\hline \multirow{3}{*}{$\begin{array}{l}\text { Maternal } \\
\text { diet } \\
\text { during } \\
\text { lactation }\end{array}$} & \multirow{3}{*}{$\begin{array}{l}\text { Time of } \\
\text { killing } \dagger\end{array}$} & \multirow{2}{*}{\multicolumn{2}{|c|}{$\begin{array}{c}\text { Wt of } \\
\text { carcass }(\mathrm{g})\end{array}$}} & \multicolumn{6}{|c|}{ Carcass composition (g) } \\
\hline & & & & \multicolumn{2}{|c|}{ Fat } & \multicolumn{2}{|c|}{ Protein } & \multicolumn{2}{|c|}{ Water } \\
\hline & & Mean & $\mathbf{S E}$ & Mean & $\mathbf{S E}$ & Mean & $\mathrm{SE}$ & Mean & SE \\
\hline & 2 & 232 & $3 \cdot 4$ & $35 \cdot 3$ & $2 \cdot 5$ & $46 \cdot 0$ & $1 \cdot 3$ & $141 \cdot 3$ & $2 \cdot 3$ \\
\hline Low-protein & 16 & $181^{* * *}$ & $4 \cdot 3$ & $13 \cdot 7^{* * *}$ & $2 \cdot 0$ & $40 \cdot 2 * *$ & 0.6 & $119 \cdot 2^{* * *}$ & $2 \cdot 3$ \\
\hline High-protein & 16 & 225 & $3 \cdot 4$ & $15 \cdot 6^{* * * *}$ & $1 \cdot 2$ & $48 \cdot 3^{*}$ & 0.8 & $152-9^{* * *}$ & 1.9 \\
\hline
\end{tabular}

Values differ from those for rats killed 2 -d post partum: $P P<0.05,{ }^{* *} P<0.01, * * * P<0.001$. + Days post partum.

Table 6. Food intakes $(14 d)$, and activities of hepatic argininosuccinate synthetase in non-pregnant and lactating rats

(Mean values and their standard errors for eight matched pairs)

\begin{tabular}{|c|c|c|c|c|c|c|c|c|c|c|}
\hline \multirow{2}{*}{$\begin{array}{l}\text { Physiological } \\
\text { status }\end{array}$} & \multicolumn{2}{|c|}{$\begin{array}{c}\text { Initial } \\
\text { body-wt (g) }\end{array}$} & \multicolumn{2}{|c|}{$\begin{array}{l}\text { Total food } \\
\text { intake }(\mathrm{g})\end{array}$} & \multicolumn{2}{|c|}{$\begin{array}{l}\text { Total protein } \\
\text { intake }(\mathrm{g})\end{array}$} & \multicolumn{2}{|c|}{$\begin{array}{l}\text { Wt of } \\
\text { liver }(\mathrm{g})\end{array}$} & \multicolumn{2}{|c|}{$\begin{array}{l}\text { Activity of } \\
\text { arginino- } \\
\text { succinate } \\
\text { synthetase } \\
\text { (i.u./liver) }\end{array}$} \\
\hline & Mean & SE & Mean & $\mathbf{S E}$ & Mean & $\mathrm{SE}$ & Mean & $\mathbf{S E}$ & Mean & SE \\
\hline Non-pregnant & 229 & 3.6 & 324 & $19 \cdot 3$ & $27 \cdot 5$ & $1 \cdot 6$ & $10 \cdot 20$ & 0.32 & 159 & 17 \\
\hline Lactating & 227 & $4 \cdot 1$ & 338 & $18 \cdot 5$ & $28 \cdot 7$ & 1.6 & $10 \cdot 22$ & 0.62 & $103^{* * *}$ & 14 \\
\hline
\end{tabular}

*** Value differs from that for non-pregnant rats: $P<0.001$

Expt 4. In the final experiment which was concerned with the metabolism of protein, rats given the low-protein diet from the second day of lactation were again allowed to suckle their pups for $14 \mathrm{~d}$. The total activity of the enzyme argininosuccinate synthetase ( $E C$ 6.3.4.5) was then determined in their livers, and the value compared with that found in virgin controls that had experienced an identical dietary regimen. Results are given in Table 6 . Total food intakes, and hence protein intakes, were very similar in the lactating and non-lactating animals. The normal hypertrophy of the liver associated with lactation (Kennedy et al. 1958) was not observed in the poorly nourished dams; their mean liver weight was the same as in the virgin controls. The total activity of argininosuccinate synthetase, a measure of the liver's capacity to synthesize urea was, however, reduced by $35 \%$.

\section{DISCUSSION}

During reproduction in the rat the metabolism of protein and of energy undergo cyclic changes that affect the storage of protein and fat in the maternal body. With protein the cycle is complete by the end of pregnancy. Protein stored during the first 2 weeks of gestation is catabolized during the period of rapid foetal growth so that, if the diet is high in protein, there is no net gain or loss from the carcass (Naismith, 1966; Naismith \& Morgan, 1976). From the results of the present investigation it may be concluded that the rat dam, given an adequate diet throughout lactation, contributes no protein from her body towards the synthesis of milk proteins.

On a moderately low protein intake, the dams experienced a substantial loss of protein from their carcasses, but this failed conspicuously to compensate for the dietary deficit. Their 
pups gained only half as much weight during the $14 \mathrm{~d}$ of lactation as did pups suckled by rats given the high-protein diet, and their carcasses contained proportionately less protein and much less fat. The high-protein diet used in the experiments not only promoted an optimal lactation, but also permitted a small increase in carcass protein. Whether this gain was due to the state of anabolism associated with lactation or to normal growth of the rats between days 2 and 16 post partum cannot be stated with certainty, but the former explanation seems the more likely. During lactation, as in pregnancy, protein anabolism was shown to be enhanced by the suppression of amino acid catabolism.

Evidence for the more efficient utilization of protein during lactation was obtained by estimating the capacity of the liver to synthesize urea. We measured the activity of the enzyme argininosuccinate synthetase which is known to respond directly to changes in protein intake, and is believed to catalyse the rate-limiting step in the pathway of urea synthesis Brown \& Cohen, 1960; Schimke, 1962). Lactating rats and virgin controls were given the low-protein diet ad lib. for $14 \mathrm{~d}$. This diet was used in the expectation that food intakes would be similar in the two groups of animals. In the event, the mean protein intake of the lactating rats was marginally higher than that of the controls. Nevertheless, the activity of argininosuccinate synthetase in their livers was substantially lower, indicating an adjustment in amino acid metabolism that favoured a more economical use of protein.

The cyclic changes affecting the utilization of energy appeared to embrace the entire reproductive period. Fat storage in the rat was found to occur at an even pace from early pregnancy, a loss of fat being detected only in the suckling period. In this respect the rat differs from the pregnant woman in whom storage ceases and some mobilization of fat normally occurs during the third trimester (Hytten, 1980). Little more than one-third of the fat was stored in the subcutaneous fat depot, the remainder being distributed in central depots in the body.

In the better nourished dams almost $60 \%$ of the total body fat was lost after $14 \mathrm{~d}$ of lactation despite an increase of approximately $50 \%$ in food intake. Thus optimum use was made of dietary protein for the synthesis of milk proteins, the energy for milk formation being derived partly from the diet and partly from the fat reserve. A rough estimate of the energy cost of lactation was made by calculating the energy value of the additional food consumed relative to the food intake of the virgin controls from Expt 4, and of the fat catabolized, and from this figure the contribution from fat was determined. In the dams consuming the high-protein diet, $23 \%$ of the energy cost of lactation was met by catabolizing body fat. A similar calculation for the dams given the low-protein diet gave a much higher value $(70 \%)$ because of the very small rise in food consumption during lactation. What was surprising was that the degree of fat mobilization was just as great in these animals although milk output, as judged by the gain in weight of their pups, or better, by the gain in carcass energy of their pups, must have been little more than one-third of that of their betternourished littermates. Had a similar amount of energy been obtained by raising the food intake rather than by catabolizing fat, the extra protein consumed $(5.2 \mathrm{~g})$ might have prevented the loss of body protein.

Since the mobilization of the fat accumulated during pregnancy is not related to lactational performance, we conclude that it is under hormonal rather than dietary control. The diet of the poorly nourished dams contained too little protein to provide a satisfactory yield of milk, even with a substantial protein subsidy from the maternal carcass. Lactation in these dams involved the subtle interaction of an exogenous (dietary) and endogenous (maternal tissue) supply of protein and energy to produce the ideal balance for milk formation. It may be inferred that, in achieving this balance, the obligatory contribution of energy from the maternal fat reserve resulted in the suppression of food (energy) intake to a level commensurate with optimum utilization of the limited protein supply. 


\section{REFERENCES}

Beaton, G. H., Beare, J., Ryu, M. H. \& McHenry, E. W. (1954). J. Nutr. 54, 291.

Brown, G. W. Jr \& Cohen, P. P. (1959). J. biol. Chem. 234, 1769.

Brown, G. W. Jr \& Cohen, P. P. (1960). Biochem. J. 75, 82.

Folch, J., Lees, M. \& Sloane-Stanley, G. H. (1957). J. biol. Chem. 226, 497.

Hervey, E. \& Hervey, G. R. (1967). J. Endocr. 37, 361.

Hytten, F. E. (1980). In Clinical Physiology in Obstetrics, p. 181 [F. E. Hytten and G. Chamberlain, editors] London: Blackwell.

Kennedy, G. C., Pearce, W. M. \& Parrott, D. M. V. (1958). J. Endocr. 17, 158.

Naismith, D. J. (1966). Metabolism 15, 582.

Naismith, D. J. (1971). Proc. Nutr. Soc. 32, 93A.

Naismith, D. J. (1980). In Maternal Nutrition During Pregnancy and Lactation, p. 16. [H. Aebi and R. Whitehead, editors]. Bern: Huber.

Naismith, D. J., Akinyanju, P. A. \& Yudkin, J. (1969). J. Nutr. 97, 375.

Naismith, D. J. \& Fears, R. B. (1971). Proc. Nutr. Soc. 31, 8A.

Naismith, D. J. \& Morgan, B. L. G. (1976). Br. J. Nutr. 36, 563.

Niiyama, Y., Endo, S., Kamori, K. \& Inoue, G. (1973). Nutr. Rep. Int. 8, 61.

Ratner, S. (1955). In Methods in Enzymology, vol II, p. 356 [R. B. Clayton, editor]. London: Academic Press.

Schimke, R. T. (1962). J. biol. Chem. 235, 459.

Spray, C. M. (1950). Br. J. Nutr. 4, 354. 